\title{
Starting a new life in the South? Swiss, Dutch and Flemish ageing in Morocco: a lifecourse perspective
}

\author{
Claudio Bolzman ${ }^{1 \star(D)}$, Tineke Fokkema ${ }^{2,3}$, Ibrahima Guissé ${ }^{4}$ and Danique van Dalen ${ }^{5}$ \\ ${ }^{1}$ Department of Social Work (Hets), University of Applied Sciences Western Switzerland (HES-SO), \\ Genève, Switzerland, ${ }^{2}$ Netherlands Interdisciplinary Demographic Institute-KNAW, University of \\ Groningen, The Hague, The Netherlands, ${ }^{3}$ Department of Public Administration and Sociology, Erasmus \\ University Rotterdam, Rotterdam, The Netherlands, ${ }^{4}$ Department of Sociology, University of Geneva, \\ Switzerland and ${ }^{5}$ Department of Political and Social Sciences, Institute of Sociology, Freie Universität \\ Berlin, Berlin, Germany \\ *Corresponding author. Email: claudio.bolzman@hesge.ch
}

(Accepted 1 December 2020)

\begin{abstract}
This article focuses on European migrants living in Morocco and now near retirement or retired. Using a lifecourse approach we are interested in whether their timing of migration to Morocco made a difference in terms of their motivations to settle there and subsequently with the social relationships at the destination. To this end, we conducted 36 biographical interviews with Swiss, Dutch and Belgian Flemish migrants aged 50 and older. Findings show the relevance of a lifecourse perspective for international migration studies. Early adulthood migrants to Morocco had no strong obligations in their home country and were ready to explore new affective or professional experiences in a new country. They had the time to discover and find a place in Moroccan society and to develop long-lasting social relationships with kin and non-kin. Middle-adulthood migrants moved with the intention of rapidly accessing a higher standard of living thanks to the tourism economy, with hedonistic perspectives in a setting with a better climate. Their social life is limited to interaction with business clients and a few like-minded migrants from Europe, and their communication with personnel is a daily challenge. Most late-in-life migrants experienced disruptive life events before migrating, and expected to find in Morocco a second chance to build a better life. They generally move in select circles of European expatriates.
\end{abstract}

Keywords: ageing migrants; Morocco; lifecourse; life events; timing of migration; linked lives

\section{Introduction}

Migration of Europeans to Morocco is a new yet growing phenomenon that deserves more scholarly attention. The aim of this article is to explore the main motivations, according to the timing of settlement, that lead Swiss, Dutch and 
Belgian Flemish nationals to move to Morocco and subsequently the social relationships they develop in this new context. Indeed, while Morocco is a new geographical frontier for all of these persons who are now 50 or older, they arrived at this destination at different moments in their lives: some of them migrated in early adulthood, some in middle adulthood and others late in life, just before or after retirement. Hence, in a broad sense they are all international near-retirement or retired migrants (INRRM), while late-in-life migrants are specifically part of the phenomenon of international retirement migration. Our main questions are:

- What are the main motivations that led these three age groups to migrate to Morocco?

- What are the social relationships they developed in Morocco while migrating to that country at different ages and under different circumstances?

This is one of the first studies to bring a lifecourse perspective to the field of lifestyle migration, allowing us not only to get a more diversified picture of INRRM's motivations to migrate, but also to examine the role of their age at migration in the challenges they face when building a new social network at the destination. Indeed, according to literature on lifecourse and social relationships, people have different needs and opportunities in the various lifestages (Luong et al., 2011), and our aim is to explore whether this applies to our three age groups.

The phenomenon of international retirement migration from North to South is gaining relevance. New mobility and migratory patterns at a worldwide scale, including new tourist and residential destinations, are emerging in a context of globalisation (Dumont, 2006). Morocco is one of these new geographical destinations, together with Senegal in sub-Saharan Africa (Sall, 2009; Guissé and Bolzman, 2014), Thailand and Malaysia in Asia (Ono, 2015; Botterill, 2017), and Mexico and Panama in Central America (Benson, 2013; Bantman-Masum, 2015; Lardiès Bosque et al., 2016).

The interest in this phenomenon of the globalisation of international retirement migration and its implications for different societies appears to be relatively recent, at least in the European context. Previous studies in this field mainly focused on intra-European international mobility: Europeans close to retirement or retirees migrating from northern Europe (United Kingdom, Germany, Switzerland, The Netherlands) to the coasts of southern Europe (Italy, Spain, Malta, Portugal) (Casado-Díaz et al., 2004; Huber and O’Reilly, 2004; Sampaio, 2017) or to rural France (Buller and Hoggart, 1994; Benson, 2011) and rural Italy (King et al., 2019). Our article transcends these geographical borders and focuses on INRRM moving beyond European destinations.

Most European studies explore pensioners' migration motivations, yet do not differentiate unambiguously whether these motivations or the social relationships of migrants vary according to lifestage at the moment of migration; instead, they give a more general picture of the main drivers intervening in migration decisions and of socialisation in the new context. As a result, they show that INRRM are mainly motivated by the desire to have access to a more attractive lifestyle in a better climate and to what they consider desirable ageing (Williams et al., 2000; Benson, 2011). The role of imaginary representations thus appears as quite 
important in ageing migrants' choice of destination country (Benson, 2011). Other studies reveal that this form of migration can be also pushed by economic reasons such as low pensions and precarious living conditions that people want to escape in their home country (Benson and O’Reilly, 2009; Botterill, 2017; Repetti and Bolzman, 2020). Yet other motivations to migrate have been less explored, like important events affecting the lifecourse at different lifestages (divorce, widowhood, health problems) or affective reasons (e.g. new partner in the destination country). This is one of the originalities and central aims of our article: to understand, from a lifecourse perspective, the main motivations that have brought Swiss, Dutch and Flemish migrants to live in Morocco and the social relationships they established in this new context.

The lifecourse perspective is starting to be used more extensively in migration studies (Kulu and Milewski, 2007; Kley, 2011; Wingens et al., 2011; Findlay et al., 2015), but has been explored more in the context of internal migration (Bernard et al., 2014), South-North high-skilled professional migration (Kirk et al., 2017; Kõu et al., 2017), East European-West European migration (Croitoru, 2018; Vlase and Voicu, 2018), return migration (Bettin et al., 2018) and second-generation trajectories (Bolzman et al., 2017; Gomensoro and Bolzman, 2019). There is almost no evidence on the use of the lifecourse paradigm in North-South migration studies. Our purpose is precisely to contribute through this new lens to the study of INRRM who have settled in the global South.

Another originality of the article is methodological, and concerns the criteria for choosing the INRRM: we focus on INRRM of three nationalities less studied because they come from small European countries (Switzerland, The Netherlands, Belgium) and their presence in Morocco represents a new social phenomenon. In recent years, Morocco has become an important tourist destination for Europeans and this trend, as shown by previous studies (Williams et al., 2000; Benson and O'Reilly, 2009), probably contributed to the subsequent settlement of nationals of these three countries. This will be further explored below.

Our article begins with a presentation of the lifecourse theoretical framework we use to analyse the European INRRM presence in Morocco. Next, we display the Moroccan context as a new destination for tourism and European migration of especially but not exclusively - pensioners. We subsequently introduce our qualitative method, the protocol for our interviews and our sample. Below we present the results by tracing the various motivations for migration of our interviewees at different stages of their lives and the eventual changes they represent in their lifecourse in terms of establishing new social relationships in the immigration context. We conclude by summarising our main findings in relation to our lifecourse framework, and discuss their association with the main dimensions of this paradigm. Lastly, we sketch avenues for future research on the mobilities and migrations of INRRM in the contemporary context of globalisation of the lifecourses.

\section{The lifecourse as a theoretical framework: the importance of timing}

The lifecourse perspective examines individual life histories in order to understand how prior events, social and economic conditions, and individual characteristics influence decisions and events over time (Edmonston, 2013). More specifically, it 
considers that an individual's life is composed of a series of transitions or life events which are embedded in trajectories or careers (or status passages) that give them a distinct form and meaning (Elder, 1994: 5; Kulu and Milewski, 2007: 568). This perspective was mainly elaborated by Glen Elder (Elder, 1994; Elder and Giele, 2009), whose work gives a theoretical direction that can be summarised in five principles: (a) life-long human development, meaning that cognitive development evolves during the entire lifecourse in interaction with other principles of the lifecourse paradigm; (b) timing, underlining that the consequences of a life event or transition depend on the age at which they are experienced; (c) linked lives, meaning that lifecourses of related persons are interdependent and affect each other; (d) agency, meaning that individuals develop expectations, have a certain degree of choice, and act intentionally in relation to the opportunities and constraints structured by the institutional contexts in which they live; and (e) time and place, indicating that lifecourses are shaped by institutional and historical contexts (Bolzman et al., 2017). We will pay special attention to the timing dimension because it has a central influence on the motivations of migrants and thus on the outcomes of migration in terms of social relationships, and was particularly helpful towards structuring our empirical data. We will also refer to the linked lives dimension, as it provides additional insight into the ways INRRM moving to Morocco at different ages build their social life in a new context while considering significant others' lives.

Individuals are greatly influenced by the timing of migration, especially in relation to other significant lifecourse transitions (Mulder, 1993). It is not the same to migrate in early adulthood, that is, at a moment of life where individuals have not yet experienced other important life events like finishing school, entering the labour market, finding a partner or starting a family, than migrating in middle adulthood, where most individuals have experienced these life events and may have been confronted with other ones, like career changes, unemployment or divorce. It is also different to migrate late in life, where issues related to the transition from work to retirement are particularly important.

INRRM living in a new country can experience migration in early adulthood, middle adulthood or near retirement age. In the first case, most events related to adult life (work, family formation, etc.) will take place in the country of emigration; in the second case, these events will take place partly in the country of origin and partly in the country of emigration, while in the last case they will occur mainly (but not exclusively) before migration. Regardless, whatever the age of migration, most people will experience a new transition - from work to retirement - in the country of emigration, but this transition will be coloured by the different backgrounds and experiences specific to the moment of migration. Indeed, the literature on migration and lifecourse has shown that social relationships in the country of destination are very different, depending on the moment of adulthood at which one moved (Wall and Bolzman, 2014), and allowing for different family and friendship configurations (Widmer, 2010) at the local level. Literature on lifestyle migration, however, does not distinguish the challenges faced by INRRM according to moment of migration and motivations to migrate. More specifically, it does not differentiate the challenges related to the creation of new social relationships at different moments of migration. This is particularly important because the types of social 
relationships needed at different moments of the lifecourse and according to migratory projects are not of the same nature (Wall and Bolzman, 2014). For instance, migrants in early adulthood are probably more concerned with creating professional and parental networks, while migrants in middle adulthood could be more worried about enhancing their social capital in line with professional motivations and late-in-life migrants could be more concerned with creating new social relationships to avoid isolation.

Timing is also related to the sequencing of events, and a change in sequencing can fundamentally affect the significance of a specific migration (Findlay et al., 2015). Hence the experience of migration can be quite different if someone migrates for affective reasons and once in the country of destination starts looking for a job or, conversely, if the person migrates because they already have a job and then starts looking for a partner in the new context. Whatever the sequence, there will be event dependence: changes in one life domain will increase the chances of change in other life domains (Bailey and Mulder, 2017).

The lifecourse notion of linked lives (that is, individuals being linked to family and social networks over their lifetime) has a special place in migration analysis because most of the time individuals do not take the migration decision alone, they are influenced quite frequently in this decision by 'significant others' like their partner, other family members, friends or employers (Edmonston, 2013). According to Kley (2011), events that dissolve bonds at the place of residence and which are likely to scatter daily routines are expected to trigger the consideration of migration. Likewise, events that are creating new ties at a possible destination are expected to trigger the decision in favouring migration.

According to different studies on internal migration, there is an association between timing of migration and linked lives. Marriage and co-habitation are among the most important motives for long-distance moves in early adulthood, especially for women. Single people are ready to take higher risks for migration than couples, with the aim of union formation (Mulder and Wagner, 1993). On the other hand, any change in marital status, including divorce and separation, significantly enhances the chances of moving (Clark and Huang, 2003; Li, 2004) - a form of delinked lives in order to create new linked lives. Because dissolving partnerships or marriages gain relevance with age (Geist and McManus, 2008), they are expected to be more important for moving in the phase of middle adulthood or even near retirement age (Kley, 2011). Along the same lines, in these two last phases having a partner who wishes to move is expected to trigger the decision in favour of migration (Kley, 2011). Traditionally, it has been women who followed their migrating husbands (Smits et al., 2003; Bailey and Mulder, 2017), but some studies show that men are also followers in the migration process (Gallo, 2006; Shaw and Charsley, 2006). By now, women have clearly conquered more spaces of autonomy that allow them to consider new ways of life, including through independent forms of migration (Lulle and King, 2016).

These two lifecourse principles - timing and linked lives - can also impact the outcomes of migration in terms of developing social relationships. For instance, the distribution of roles and tasks among partners, including the possibility of external contacts through work, family, and leisure or volunteer activities are not the same if migration occurs in young or late adulthood (Gilmartin and Migge, 
2016). With respect to linked lives, migrants who move to get married to someone who already lives in another country will not experience migration in the same way as those who migrate with their partner or move alone, because those following their partner will probably have more opportunities to be quickly introduced to local society. Individuals who experience the loss of an important link in the country of origin after events like divorce or widowhood will not perceive migration in the same way as those migrants who are still married. But whatever the age or the relational situation, migration is a life event that probably introduces some discontinuity in migrants' lives, leading them to discover new paths and take novel life turns, including new social relationships. We will explore whether these new social relationships include people who are part of local society or whether they are (also) expatriates. It is also a question of analysing the types of relationship that are established between INRRM and these locals, that is, whether these are friendships or rather instrumental relationships.

Before exploring these issues, it is important to understand the Moroccan context that makes the country a potentially attractive destination for Europeans, especially ageing migrants.

\section{The Moroccan context and European migration}

With the increasing complexity of migration flows, Morocco, a traditional country of emigration, has also become a country of immigration. Besides a South-South migration, mainly from sub-Saharan Africa, ${ }^{1}$ there is a North-South migration trend composed of expatriates and retirees from various countries, especially France (Berriane et al., 2015). According to the website Challenges.fr, Morocco is the favourite destination of French nationals who choose to retire outside France without having any family ties in the new country. There are as many as 20,00025,000 French pensioners, which is about half of the estimated French resident population in Morocco (Terrazzoni, 2015). The Moroccan Association for Studies and Research on Migration mentions online that 'European seniors are ageing in Morocco' (Econosrum.info) with the support of the Moroccan authorities, who practise a policy of attracting retired Western migrants. In this regard, Econosrum.info identifies several real-estate projects aiming to accommodate growing numbers of European seniors. ${ }^{2}$

More broadly speaking, Morocco has become a country of tourist and residential attraction for European nationals. In the first four months of 2019, the number of tourists stood at 3.6 million. ${ }^{3}$ Among the most popular destinations are Marrakech, Agadir and Essaouira. These regions have experienced the strongest urban expansion and population growth in recent years (Terrazzoni, 2015). For example, between 2001 and 2009 the capacity of tourist accommodation in Essaouira multiplied by 2.5 (the highest increase in Moroccan cities). According to estimates by the Directorate of Studies and Financial Forecasts (Direction des études et des prévisions financières), most of the tourist activity in Morocco takes place in Marrakech, which can be seen as the cultural and historical heart of the country. In 2017, a record number of 2.5 million tourists visited Marrakech. After Marrakech, the highest number of overnight stays were booked in the region of Sousss-Massa-Drâa (Agadir), with a total of 5.1 million stays. ${ }^{4}$ Many studies have 
shown that there is a strong association between tourist destinations and lifestyle migration (Williams et al., 2000; Benson and O'Reilly, 2009), and Morocco is no exception (Bousta, 2007; Therrien and Pellegrini, 2015).

During our fieldwork in these regions, we have observed a growing number of economic activities related to the presence of the European population that offer services to tourists (accommodation, catering) as well as to new European residents (real estate, residential secondary care, interior design). Moreover, a number of new large properties built in the surroundings of Marrakech and Essaouira are intended for European clients. There are also many guesthouses run by Europeans who have developed the concept of rural accommodation. In the medina (old town), the main streets display a succession of riads or dars, traditional urban houses, transformed into guesthouses and also owned mostly by Europeans. According to Escher and Petermann (2014), the old city of Marrakech has become a destination for many lifestyle migrants from all over the world: more than 2,500 foreigners have bought overcrowded, neglected or vacant buildings and transformed them into riads.

According to the Organisation for Economic Co-operation and Development (2017), immigrants from Western countries represent 21 per cent of all immigrants living in Morocco. The main source of European residents in Morocco is France, because of the historical and current economic and institutional links that connect the two countries. It has also become a popular destination for tourists and migrants from other European countries like Switzerland, the Netherlands and Belgium. Direct low-cost flights between the main airports in these countries and Marrakech or Agadir foster travel and mobility, as does the presence of a large population of Moroccan background living in Belgium and the Netherlands (Martiniello and Bousseta, 2008; Solano, 2019). The fact that French is an official language in Belgium and Switzerland could also make Morocco an attraction. Yet migration of Swiss, Dutch and Belgian nationals does remain modest compared to other destinations like Spain and Portugal. In 2017, there were 1,495 Swiss living in Morocco, 342 (one-fifth) older than 65. In Spain, the number of Swiss aged 65 and older was 7,562, over 20 times more than in Morocco (Office fédéral de la statistique, 2017). The only figures we could find on Dutch and Belgians living in Morocco are from 2010. In that year there were 1,018 Belgians and 300 Dutch officially living in Morocco (Khachani, 2011). The number of Europeans living in Morocco is probably underestimated by official figures. Indeed, many European residents do not necessarily declare their long-term presence to their home country's consulate or to the Moroccan authorities. ${ }^{5}$

\section{Methodology}

Our analysis is based on data collected during two qualitative research studies using biographical interviews: one for December 2014 to May 2016 among French- and German-speaking Swiss older adults in Casablanca, Rabat, Essaouira and the Marrakech area by the Swiss research team, the other for September 2016 to March 2017 among Dutch and Flemish older adults in Essaouira, the Agadir and Marrakech areas, and some smaller localities (Tafraoute, Ouzoud, N'kob) by the Dutch research team. The two studies had a similar focus-migrants aged 50 and older living in Morocco-and a co-ordinated methodology: researchers 
circulated their interview guides and the translated interviews; they also exchanged systematically on the content analysis of the interviews. We did not interview French INRRM, as we are interested in INRRM from countries that did not have a previous colonial relationship with Morocco. Besides, while there have been some studies about lifestyle French migrants in Morocco (see the previous section), this is not the case for other European migrants.

Some interviewees left Switzerland, the Netherlands and Belgium after completing their professional career or just before retirement, while others migrated earlier in the lifecourse and are ageing in place. All in all, we conducted 13 biographical interviews with Swiss nationals, 16 with Dutch nationals and seven with Belgian Flemish. ${ }^{6}$ Most were individual interviews, but in six cases the couple was interviewed together. The sample includes 20 men and 22 women who agreed to participate in the research. It is important to emphasise that our sample does not include persons of Moroccan origin who had lived in Europe and later returned to their home country.

We contacted Swiss nationals through the Swiss Consulate in Rabat (which put us in contact with several people), interpersonal contacts (two interviewees) and social networks (two interviewees). In addition, people contacted through the consulate and interpersonal relationships connected us with some of their acquaintances and friends, allowing us to expand the sample. For the Dutch and Flemish cases, we searched the internet to find Dutch and Flemish individuals working in the Moroccan tourism industry (e.g. owner of a riad or camp site). One of the couples provided us with contact details of the chairman of a former Dutch-speaking club in Morocco. Through him we were able to conduct a second round of interviews. The remainder of the interviewees were found through snowball sampling. Of course, this is an exploratory study and our sample is not statistically representative. It nevertheless offers a first insight into understudied INRRM in Morocco.

The data on which this article was constructed were obtained in interview situations, that is to say during a situation of interaction between a narrator (or two narrators in the case of some couples who were interviewed together) and an interviewer (Josselson and Lieblich, 1993). These are relatively short biographical stories covering significant periods of the person's adult life (Bertaux and Kohli, 1984; Rosenthal, 1993) as well as the years prior to migration and life in Morocco. More precisely, the main dimensions of the interviewing guide in both studies were: main motivations for moving to Morocco; reason for settling in that particular locality; professional and social situation in the home country before coming to Morocco; economic situation in Morocco; principal sources of income; health situation and access to health services; perception of Moroccan culture; social relationships; relations with the local population; transnational ties; and socio-demographic data. The languages of the interviews were French for the Swiss and Dutch for the Dutch and the Flemish. The interviews took place mostly at private homes and sometimes in public spaces like cafés and restaurants. Two interviews were done via Skype. All interviews were recorded with the permission of the participants, and lasted between one and three-and-a-half hours. All the registered interviews were transcribed and comprehensively coded in a co-ordinated way by both teams. We subsequently conducted a thematic content analysis based 
on the interviewing guide and many exchanges of materials and systematic discussions between the researchers. The main dimensions retained for the analysis were thus the same as appears in this guide, but for this article, we focused mainly on two of them: motivations for migrating to Morocco, and social relationships with locals and expatriates in Morocco. Table 1 describes the main characteristics of the interviewees, all of whom have been given a pseudonym.

\section{Results}

The timing dimension of the lifecourse perspective has structured our analysis. We accordingly distinguish three groups among the interviewees: early adulthood, middle-adulthood and late-in-life migrants to Morocco.

\section{Ageing migrants who moved in early adulthood}

For those who migrated at the early stages of their adulthood, before the age of 35 , Morocco was not a planned destination. The women in this case (with the exception of Aletta) fell in love with a Moroccan man and decided to follow him to Morocco, where they got married, established themselves and (with the exception of Charlotte) started a family. Hence for them the main reason for coming to Morocco was clearly affective. The fact that these women emigrated at a young age was to some extent expected. They did not feel strongly attached to the job they had and felt the urge to spread their wings. Before migration, many had already expanded their horizons, experiencing other cultures by studying or working abroad and travelling frequently. It was at university or during a vacation to Morocco that they met their present husbands. At a certain point in their life, all these women combined household and child-care tasks with a paid job. The jobs were diverse, but one common characteristic they share is that they worked in an international setting (e.g. Swiss organisation, multinational company, owner of a riad).

Aletta from the Netherlands was the only woman who migrated to Morocco at a young age for another reason, albeit also in a family context. She joined her Dutch husband, who got a good position in the financial sector in Casablanca, and started a family. During one of the many receptions she attended with her husband she decided to take more advantage of these social events by organising benefits for orphans. When her husband died, she set up her own orphanage near Marrakech. She is now in her eighties and still running this orphanage together with her daughter.

For the three men who migrated at a young age, two Swiss and one Flemish, the reasons were more heterogeneous. Still, the common thread is that Morocco was an opportunity to expand their horizons, an 'exotic' place to try new life and work experiences. Edouard from Switzerland, aged 70, arrived in Morocco 37 years ago with the idea of starting his own business. He ended up working as a manager for a French company. He married a French woman born in Morocco and started a family there. Claude (age 68), also Swiss, wanted to travel and discover other countries. He had followed optician's training in Switzerland and had an opportunity to work in Morocco. He married a Moroccan woman and after several years working as an optician in a Moroccan company, he became a painter. Victor (age 56), from 
Table 1. Main characteristics of the interviewees

\begin{tabular}{|c|c|c|c|c|c|c|c|}
\hline Pseudonym & $\begin{array}{l}\text { Country } \\
\text { of origin }\end{array}$ & Age & $\begin{array}{l}\text { Years in } \\
\text { Morocco }\end{array}$ & Migration motive & $\begin{array}{l}\text { Profession before } \\
\text { Morocco }\end{array}$ & $\begin{array}{l}\text { Profession in } \\
\text { Morocco }\end{array}$ & Marital status \\
\hline \multicolumn{8}{|c|}{ Migrated at young age: } \\
\hline Jessica (F) & CHFR & 66 & 40 & $\begin{array}{l}\text { Moved to marry a } \\
\text { Moroccan partner }\end{array}$ & Secretary & $\begin{array}{l}\text { Housewife/employee } \\
\text { in Swiss enterprises } \\
\text { in Morocco }\end{array}$ & $\begin{array}{l}\text { Married to a Moroccan } \\
\text { man }\end{array}$ \\
\hline Ingrid (F) & CHDE & 73 & 46 & $\begin{array}{l}\text { Moved to marry a } \\
\text { Moroccan partner }\end{array}$ & $\begin{array}{l}\text { Employee in different } \\
\text { companies }\end{array}$ & $\begin{array}{l}\text { Housewife/employee } \\
\text { in Swiss enterprises } \\
\text { in Morocco }\end{array}$ & $\begin{array}{l}\text { Married to a Moroccan } \\
\text { man }\end{array}$ \\
\hline Vanessa (F) & CHDE & 65 & 37 & $\begin{array}{l}\text { Moved to marry a } \\
\text { Moroccan partner }\end{array}$ & Student/employee & $\begin{array}{l}\text { Housewife/employee } \\
\text { in Swiss enterprises } \\
\text { in Morocco }\end{array}$ & $\begin{array}{l}\text { Married to a Moroccan } \\
\text { man }\end{array}$ \\
\hline Edouard (M) & CHFR & 70 & 37 & Work opportunity & Manager & $\begin{array}{l}\text { Manager, } \\
\text { businessman/retired }\end{array}$ & $\begin{array}{l}\text { Married to a French } \\
\text { woman }\end{array}$ \\
\hline Claude (M) & CHFR & 68 & 38 & $\begin{array}{l}\text { Professional } \\
\text { opportunity }\end{array}$ & Optician, technician & $\begin{array}{l}\text { Optician, artist } \\
\text { painter }\end{array}$ & $\begin{array}{l}\text { Married to a Moroccan } \\
\text { woman }\end{array}$ \\
\hline Ellen (F) & NL & 63 & 36 & $\begin{array}{l}\text { Moved with Moroccan } \\
\text { husband }\end{array}$ & $\begin{array}{l}\text { Worked at a printing } \\
\text { house, au pair in France }\end{array}$ & Secretary, retired & $\begin{array}{l}\text { Married to a Moroccan } \\
\text { man }\end{array}$ \\
\hline Aletta (F) & NL & 81 & 53 & $\begin{array}{l}\text { Work opportunity for } \\
\text { first husband }\end{array}$ & Housewife & $\begin{array}{l}\text { Director of } \\
\text { orphanage }\end{array}$ & $\begin{array}{l}\text { Married (second marriage } \\
\text { after widowhood) to a } \\
\text { Dutch man (lives in NL) }\end{array}$ \\
\hline Marjon (F) & $\mathrm{BE}$ & 58 & 37 & $\begin{array}{l}\text { Moved to live with } \\
\text { Moroccan boyfriend }\end{array}$ & Secretary/receptionist & Housewife/secretary & $\begin{array}{l}\text { Married to a Moroccan } \\
\text { man }\end{array}$ \\
\hline Charlotte (F) & $\mathrm{BE}$ & 55 & 23 & $\begin{array}{l}\text { Moved to marry a } \\
\text { Moroccan partner }\end{array}$ & Student & Owner of riad & $\begin{array}{l}\text { Married to a Moroccan } \\
\text { man }\end{array}$ \\
\hline Victor (M) & $\mathrm{BE}$ & 56 & 30 & $\begin{array}{l}\text { Escaped conscription } \\
\text { in Belgium; work } \\
\text { opportunity }\end{array}$ & Architect & Architect & $\begin{array}{l}\text { Married to a Belgian } \\
\text { woman }\end{array}$ \\
\hline
\end{tabular}




\begin{tabular}{|c|c|c|c|c|c|c|c|}
\hline Petra (F) & NL & 49 & 12 & $\begin{array}{l}\text { Fell in love with } \\
\text { Morocco }\end{array}$ & Event manager & $\begin{array}{l}\text { Organises cooking } \\
\text { workshops }\end{array}$ & $\begin{array}{l}\text { Married to a man from } \\
\text { Ivory Coast }\end{array}$ \\
\hline Wilma (F) & NL & 56 & 12 & $\begin{array}{l}\text { Fell in love with } \\
\text { Morocco; wanted to } \\
\text { leave the country }\end{array}$ & Administrative assistant & Owner of hotel & $\begin{array}{l}\text { Married to a Moroccan } \\
\text { man (much younger) }\end{array}$ \\
\hline Peter (M) & NL & 53 & 1 & Work opportunity & $\begin{array}{l}\text { Several jobs in hotel } \\
\text { business }\end{array}$ & Hotel manager & Single, never married \\
\hline Albert (M) & NL & 51 & 10 & $\begin{array}{l}\text { Fell in love with } \\
\text { Morocco; wanted to } \\
\text { leave the country }\end{array}$ & $\begin{array}{l}\text { Owner of } \\
\text { telecommunication } \\
\text { company }\end{array}$ & Owner of camp site & $\begin{array}{l}\text { Married to a Dutch } \\
\text { woman }\end{array}$ \\
\hline Tom (M) & NL & 52 & 12 & Work opportunity & Financial business & Working in real-estate & $\begin{array}{l}\text { Married to a French } \\
\text { woman }\end{array}$ \\
\hline Vincent (M) & NL & 49 & 6 & $\begin{array}{l}\text { Fell in love with } \\
\text { Morocco; climate; } \\
\text { cheap life }\end{array}$ & Worked in real-estate & Real-estate & $\begin{array}{l}\text { Living together with } \\
\text { Moroccan partner } \\
\text { (same-sex, older, born in } \\
\text { Morocco but migrated as } \\
\text { child to France) }\end{array}$ \\
\hline $\begin{array}{l}\text { Lucas (M) } \\
\text { and Emma } \\
(\mathrm{F})\end{array}$ & NL & M: 60, F: 56 & 12 & $\begin{array}{l}\text { Fell in love with } \\
\text { Morocco; wanted to } \\
\text { escape their busy } \\
\text { lives }\end{array}$ & $\begin{array}{l}\text { M: Financial director, } \\
\text { F: Marketing business, }\end{array}$ & Owner of riad & Married \\
\hline Daan (M) & BE & 51 & 12 & $\begin{array}{l}\text { Work opportunity for } \\
\text { partner }\end{array}$ & $\begin{array}{l}\text { Food and beverage } \\
\text { manager in hotel }\end{array}$ & Working in riad & $\begin{array}{l}\text { Living together with } \\
\text { Belgium partner } \\
\text { (same-sex, much younger) }\end{array}$ \\
\hline Simon (M) & BE & 58 & 8 & $\begin{array}{l}\text { Fell in love with } \\
\text { Morocco }\end{array}$ & Worked on a ship & Owner of riad & Single, never married \\
\hline $\begin{array}{l}\text { Arthur (M) } \\
\text { and Elise (F) }\end{array}$ & $\mathrm{BE}$ & M: 49, F: 49 & 13 & $\begin{array}{l}\text { Wished to live in a } \\
\text { foreign country }\end{array}$ & $\begin{array}{l}\text { M: Medical } \\
\text { representative, F: Worked } \\
\text { in cinema business }\end{array}$ & $\begin{array}{l}\text { Business in leather } \\
\text { accessories }\end{array}$ & Married \\
\hline
\end{tabular}


Table 1. (Continued.)

\begin{tabular}{|c|c|c|c|c|c|c|c|}
\hline Pseudonym & $\begin{array}{l}\text { Country } \\
\text { of origin }\end{array}$ & Age & $\begin{array}{l}\text { Years in } \\
\text { Morocco }\end{array}$ & Migration motive & $\begin{array}{l}\text { Profession before } \\
\text { Morocco }\end{array}$ & $\begin{array}{l}\text { Profession in } \\
\text { Morocco }\end{array}$ & Marital status \\
\hline \multicolumn{8}{|c|}{ Migrated at older age: } \\
\hline Brigitte $(F)$ & CHFR & 63 & 4 & $\begin{array}{l}\text { Cheap life; place for } \\
\text { everybody }\end{array}$ & White-collar post office & Retired & Divorced \\
\hline Rita (F) & CHDE & 67 & 5 & $\begin{array}{l}\text { Moved for health } \\
\text { reasons; perfect } \\
\text { climate }\end{array}$ & Saleswoman & Retired & $\begin{array}{l}\text { Divorced (lives with a } \\
\text { Moroccan man) }\end{array}$ \\
\hline Helga (F) & $\begin{array}{l}\text { DE (lived } \\
\text { in } \mathrm{CH} \text { ) }\end{array}$ & 65 & 2 & $\begin{array}{l}\text { Moved for health } \\
\text { reasons }\end{array}$ & Employed & Retired & Single, never married \\
\hline Eliane (F) & CHFR & 63 & 5 & $\begin{array}{l}\text { Fell in love with } \\
\text { Morocco }\end{array}$ & $\begin{array}{l}\text { Director of social } \\
\text { institution }\end{array}$ & Retired & $\begin{array}{l}\text { Divorced (lives with a } \\
\text { Moroccan man) }\end{array}$ \\
\hline Charles (M) & CHFR & 66 & 6 & $\begin{array}{l}\text { Moved to live with } \\
\text { Moroccan partner; } \\
\text { discover other culture }\end{array}$ & $\begin{array}{l}\text { Secondary school } \\
\text { teacher }\end{array}$ & Retired & $\begin{array}{l}\text { Married (second marriage } \\
\text { after divorce) to a } \\
\text { Moroccan woman (living } \\
\text { in Switzerland) }\end{array}$ \\
\hline Gilles (M) & CHFR & 65 & 2 & $\begin{array}{l}\text { Moved to marry a } \\
\text { Moroccan partner; } \\
\text { start a new life }\end{array}$ & Manager & Owner of guest house & $\begin{array}{l}\text { Married (second marriage } \\
\text { after divorce) to a } \\
\text { Moroccan woman }\end{array}$ \\
\hline Serge (M) & CHFR & 64 & 7 & $\begin{array}{l}\text { Moved to marry a } \\
\text { Moroccan partner }\end{array}$ & Chef & $\begin{array}{l}\text { Owner of studios } \\
\text { (small apartments) }\end{array}$ & $\begin{array}{l}\text { Married (second marriage } \\
\text { after divorce) to a } \\
\text { Moroccan woman }\end{array}$ \\
\hline Frédéric (M) & CHFR & 61 & 4 & $\begin{array}{l}\text { Professional } \\
\text { opportunities for } \\
\text { business }\end{array}$ & Businessman & Businessman & $\begin{array}{l}\text { Divorced (lives with a } \\
\text { Moroccan partner) }\end{array}$ \\
\hline Laura (F) & $\mathrm{NL}$ & 61 & 4 & $\begin{array}{l}\text { Fell in love with } \\
\text { Morocco }\end{array}$ & Civil servant & $\begin{array}{l}\text { Tourism business } \\
\text { (including renting out } \\
\text { part of her house to } \\
\text { tourists) }\end{array}$ & Divorced \\
\hline
\end{tabular}




\begin{tabular}{|c|c|c|c|c|c|c|c|}
\hline Bram (M) & $\mathrm{NL}$ & 72 & 7 & $\begin{array}{l}\text { Fell in love with } \\
\text { Morocco; wanted to } \\
\text { spend winter } \\
\text { somewhere warmer }\end{array}$ & $\begin{array}{l}\text { Worked in an } \\
\text { Information Technology } \\
\text { department }\end{array}$ & Owner of riad & Divorced \\
\hline Nora (F) & $\mathrm{NL}$ & $\begin{array}{l}\text { Unknown } \\
\text { (late sixties) }\end{array}$ & 11 & $\begin{array}{l}\text { Cheap life; great } \\
\text { climate }\end{array}$ & Teacher & Retired & Married to an Italian man \\
\hline $\begin{array}{l}\text { Louis (M) and } \\
\text { Olga (F) }\end{array}$ & $\mathrm{NL}$ & M: 65, F: 63 & 5 & Retirement & $\begin{array}{l}\text { M: Chemistry teacher, } \\
\text { F: Never worked }\end{array}$ & Retired & Married \\
\hline $\begin{array}{l}\text { Floris (M) and } \\
\text { Isabel (F) }\end{array}$ & $\mathrm{NL}$ & M: 65, F: 63 & 7 & $\begin{array}{l}\text { Retirement; lived in } \\
\text { Morocco before (both } \\
\text { as child) }\end{array}$ & M: Chemist, F: Lawyer & Retired & Married \\
\hline $\begin{array}{l}\text { Jan }(M) \text { and } \\
\text { Berta }(F)\end{array}$ & $\mathrm{NL}$ & M: 62, F: 58 & 6 & $\begin{array}{l}\text { Fell in love with } \\
\text { Morocco; cheap life }\end{array}$ & $\begin{array}{l}\text { Both worked in health } \\
\text { care }\end{array}$ & No job & $\begin{array}{l}\text { Married (second } \\
\text { marriage) }\end{array}$ \\
\hline $\begin{array}{l}\text { Klaas (M) and } \\
\text { Cora (F) }\end{array}$ & $\mathrm{NL}$ & M: $85, F: 80$ & 11 & $\begin{array}{l}\text { Health reasons; } \\
\text { cheaper life }\end{array}$ & $\begin{array}{l}\text { M: project developer, } \\
\text { F: Teacher }\end{array}$ & Retired & $\begin{array}{l}\text { Married (second } \\
\text { marriage) }\end{array}$ \\
\hline Marie (F) & $\mathrm{BE}$ & 66 & 7 & $\begin{array}{l}\text { Moved with Moroccan } \\
\text { husband }\end{array}$ & $\begin{array}{l}\text { Manager in international } \\
\text { organisations }\end{array}$ & Owner of riad & $\begin{array}{l}\text { Married (second marriage } \\
\text { after divorce) to a } \\
\text { Moroccan man (much } \\
\text { younger) }\end{array}$ \\
\hline
\end{tabular}

Notes: $\mathrm{N}=36$. F: female. M: male. CHFR: French-speaking Switzerland. CHDE: German-speaking Switzerland. NL: The Netherlands. BE: Flemish Belgium. DE: Germany. CH: Switzerland. 
Belgium, escaped army conscription by coming to Agadir with his girlfriend, whom he married some years later. In Agadir, there were many opportunities for him to find a job as a newly graduated architect. He started as a teacher at a technical school that trained assistants for architects or engineers. However, there were certainly other reasons for choosing this particular location - the Mediterranean climate and lifestyle as well as the great surf spots in the surroundings of Agadir:

We had one curriculum, I think 22 hours a week for two [teachers]. And then for the rest it was surfing, windsurfing ... The job wasn't that interesting ... But it was fun in the sense of having a lot of free time, sun, good times.

After a few years, Victor succeeded in setting up his own architectural practice with mainly foreign clients.

Overall, those who migrated at a young age are still satisfied with their life in Morocco and have no intention of returning. They have been in Morocco for years, having built their family, working and social life there, and regard the country as their final destiny. As expressed by Claude (from Switzerland):

I am established in Morocco. My life has been here for a long time, this is where I made my professional life, my ties are here.

They have adapted well to Morocco, that is to say, over the years they have learned how to react to and deal with cultural differences. They are also keenly aware of the central values in Moroccan society and follow the basic rules in important events. Like Edouard (from Switzerland), who acted the right way after someone died:

If you learn of someone's death, you go right away to give condolences. You have to do it, even if it's 600 kilometres away. I did it, a Belgian guy who used to work with us did not. He just sent a note four days later. It was a shame for him ... Honour is very important here, don't be ashamed.

Moreover, several female interviewees of this group are committed to the most vulnerable Moroccans: besides the Dutch owner of an orphanage (Aletta, see above), the three Swiss women are part of an association that knits and distributes clothes for children of single mothers, and one of them (Vanessa) cares for orphan and disabled children as well. All of them acquired the basics of dialectal Arabic and hence they can 'manage in everyday life'. Nonetheless, the primary spoken language, both in and outside the home, is French.

Their long stay in Morocco has given them the opportunity to build a wide and diverse network. Besides frequent face-to-face contact with their family/in-laws, they have regular social get-togethers with long-standing friends. These friends are mainly mixed couples, individuals of foreign origin who (like them) are married to a Moroccan, and a few Moroccan current and former colleagues, most of them belonging to the upper middle classes. The lack of close contact with neighbours is explained by the Moroccan culture. In contrast to Switzerland, the Netherlands and Belgium, in Morocco it is not common to invite neighbours outside the family. Ellen (from the Netherlands) summarises it: 
I have no close contact with the neighbours. Anyway, neighbours don't have much contact. We see each other, we say hello, but we don't visit each other at home.

A possible reason for the small number of intimate contacts with the wider community is their current or past international working environment. For those women who married a Moroccan it is highly likely that their husbands' preferences play a role too, e.g. the wish to be at home in their spare time and not needing to be too close to their 'own people'.

\section{Ageing migrants who moved in middle adulthood}

The second group, who migrated to Morocco at ages 35-54, is very distinct from the younger migrants in many aspects. They already lived through the phase of finishing studies, entering the work force and starting a relationship for the first time; they were looking for a new adventure as a path to 'professional fulfilment' (Therrien and Pellegrini, 2015: 612). What certainly differentiates this group from the migrants who moved to Morocco in their early adulthood is a now-or-never feeling, which is discernible in almost all of the ten interviews. Most of these people really fell in love with Morocco in previous visits, and in combination with a very benign economic environment, they felt like they had to make the move now, before it is too late. During this phase of their life, they were still able to create economic opportunities for themselves before retirement and subsequently build a new life. What is more, they were not constrained socially: all were childless and their parents had not reached the age of highest risk of care dependency. The analysis of this group of migrants shows that they share a 'cosmopolitan identity' with the group of early adulthood migrants. They are familiar with travelling outside the borders of their home country, are comfortable with living in other countries and see the world as a place where you can work anywhere.

For these migrants, the economic dimension was of great importance while deliberating whether to move to this non-traditional migration country. The economic context can be divided into three different parts, namely lower living costs, the booming tourism sector and cheaper personnel than in European countries. Firstly, a significant proportion of the interviewees left for Morocco with reduced cost of living as the main reason. They talk about the fact that in Morocco it is more affordable to buy a house or build it yourself. Daily shopping is relatively inexpensive and overall life is simply cheaper. Vincent, a 49-year-old Dutchman who works in the real-estate industry and lives with his same-sex partner in a luxury villa in one of the exclusive golf resorts of Marrakech, tells it as follows:

The advantage if you live here, you can afford a luxury that you can no longer afford in Europe ... You can buy a house, a nice house that costs relatively less than what you can find in Europe.

Secondly, they found employment or started a business in the tourism sector, e.g. organising cooking workshops for tourists, working as real-estate agents, starting their own hotel or camp site; the only exception are Arthur and Elise, a Belgian couple who started a business in leather accessories more than ten years ago for the international market in Agadir. The accommodations that interviewees own or 
work for vary from small riads with a few rooms to very luxurious, expensive hotels. Their opportunity to find employment or start a business in tourism was made possible by the booming tourism industry in Morocco, whose remarkable growth in the last 10-20 years is something these migrants knew how to take advantage of. Thirdly, apart from low staff costs for their own business, many interviewees can afford to hire household staff - a nanny, cleaner, gardener, handyman; a standard of life with service personnel would have never been possible in their country of origin. As Elise (from Belgium) states:

If you only take the quality of life into consideration. We also have a nanny, a live-in nanny. We could never have done that in Belgium.

Generally, the migrants who moved between ages 35 and 54 seem to be content with their newly built life and the moment is not opportune to make any plans to return, stay or migrate to a third country. Multiple participants mentioned as many lifestyle migrants do - that they primarily moved to have a new life in a warmer climate and the favourable economic situation, yet they consider their residence in Morocco as a temporary episode. None seemed really interested in the actual Moroccan culture or people but moved 'simply' as a new chapter of their personal or working life. They speak little or no Arabic or Berber, and everyday life mainly revolves around their work activities. This kind of lifestyle does come with some specific consequences in terms of their social network in Morocco. Most of them seem to live in their own world, only spending time with their business clients and having occasional get-togethers with other like-minded migrants from Europe. The contact with locals is very much restricted to communication with personnel, which does not always go smoothly. They provided many examples of misunderstandings and conflicts in this respect. Most find it hard to build a 'healthy' employer-employee relationship towards personnel, keeping a balance between being personally interested in and supportive of the staff and their families while also knowing how to occasionally 'tighten the reigns to avoid getting tricked'. Examples of scams by the staff, either experienced first-hand or related by others, are illegally renting out the riad or their family using the house when the owner is on holiday, and withholding half of the meat meant for riad guests for personal use. Especially in less serious cases and when highly dependent on the staff they often choose to turn a blind eye, as told by Elise (from Belgium):

I must say the nanny is very good with the kids. The household is a little less. She cannot cook at all ... But of course you have to put up with a lot. Had we really been on our toes, we would probably have been at nanny 36 by now.

The relationship between the migrants and their personnel is an ongoing learning experience for some. One has to 'keep the hierarchical distance', which is - as for Elise - contrary to their nature and former experiences in their country of birth:

I have always considered the people who worked for me to be equals. And you absolutely mustn't do that here. You have to put yourself above the other. And sometimes that stings, but of course you mustn't show it. 
The migrants are also surprised by how easily employees choose other Moroccans over non-Moroccans that they have known for years. Peter, a 53-year-old Dutch hotel manager in the Marrakech area, noted in this respect:

Even though you've been working here with people for 15 years, the moment you have a conflict with another Moroccan they let you down.

Some migrants have occasional contact with locals in their neighbourhoods, but conversations remain very superficial. Many would like to have more contact with their neighbours, but they realise that it takes a long time to gain the trust of Moroccans. Simon, a 58-year-old Belgian who moved from Agadir to Marrakech a few years ago to start a riad there, says:

I'm really doing my best [to get in touch with the neighbours], but it takes years to get accepted here. I had the same experience in [district in Agadir]. It took three years before I was part of the neighbourhood.

Moreover, they are sceptical as to whether they will ever be able to integrate fully into the community and make real friends with Moroccans, as 'they keep seeing us as tourists and always judge us on that', but also because of differences in culture and lifestyle. With regard to the latter, Daan (from Belgium), homosexual and atheist, states:

I am with a man. We never say anything about that to other people anyway. I don't think you should do that either. The neighbours sometimes say: 'I've seen your brother' ... But that ensures that you can never build real friendships, because you can never be yourself. As long as you're not included, if you cannot be completely yourself, if you're not respected for who you are, it is hard to build real friendships.

\section{Ageing migrants who moved late in life}

The last group consists of migrants who decided to migrate to Morocco after reaching the age of 55 . They are more heterogeneous than the two previously discussed groups. Although most of them are retired, the motivations behind their migration to Morocco and its outcomes in terms of social relationships differ considerably. One common feature of late-in-life migrants is that they have experienced (a combination of) important turning points in their lives before migrating: divorce, unemployment, health problems, retirement. They perceive their settlement in Morocco as the opportunity to start a new life: new partner, new economic activity, improving health condition, new leisure activities.

For those who had experienced a divorce, one of the main motivations for settling in Morocco was the possibility of starting a new life from the affective angle. However, with two exceptions (Marie and Bram) there is a gender difference: while the divorced women fell in love with the country when visiting as a tourist, the divorced men fell in love with a Moroccan woman. One example of these women is 61-year-old Laura from the Netherlands, divorced at age 52 after 31 
years of marriage. On the advice of a girlfriend, she went on a group trip to Morocco and enjoyed all the smells and colours, the people and the food. She felt particularly comfortable in Essaouira, her current place of residence:

Here I walked alone in the streets and I could walk quietly without being bothered. And then I thought wow, this is cool.

Immediately after returning to the Netherlands, she started learning some Arabic. Her teacher was a Moroccan woman, who also taught her Moroccan cuisine and customs. In the years that followed, she spent all her holidays in Essaouira and other parts of Morocco, until, on the most beautiful outdoor café in Essaouira, she said to herself: 'Come on, Laura, if you want this so much, go for it.' Not much later, she resigned from her job and left for Essaouira, where she rented a house and started to work in tourism (renting out part of her house and organising tours). Like the other divorced women, after settling she was in a relationship with a Moroccan man, but not married.

With the exception of Bram from the Netherlands, the divorced men, all Swiss, decided to start a new life in Morocco with their new spouse or partner. Most of them knew each other via the internet. While Moroccan partners of the divorced women are close to their age (except for Marie), these Swiss men have relationships with younger Moroccan women-like Charles, aged 66, who was a teacher in Switzerland, had already lived in Africa and loved that continent. Through the internet he got in touch with Samira, aged 37. After a few months of visiting each other in Morocco and Switzerland, they had a civil marriage in Switzerland, without conversion to Islam. He believes that his knowledge of African culture allows him to negotiate an everyday space of freedom without renouncing his ideas. Charles has a comfortable retirement pension that allowed him to buy an apartment in Essaouira. He goes back and forth between Morocco and Switzerland, where his wife works. They have chosen to be a couple living together part of the year and apart the rest of the time. For Charles, life in Morocco is part of a broadening of his horizons of identity and culture:

So, one day I ended up saying to myself: I quit the job and I go to Africa! I built myself a retirement life. I led an identity quest. Through my quest I would like to deconstruct my ethnocentrism to enrich myself with the culture of others. ${ }^{7}$

For some of these women and men, migration has also resulted in a new working life. Like the middle-aged migrants, most of them work in tourism, which is either a pleasant financial supplement to their pension or an economic necessity. However, even if money played no role, there are other reasons why they are happy with their active life. For example, Gilles, a Swiss man aged 65, who with his newly married Moroccan wife set up a guesthouse near a golf course mainly for a European clientele, explains:

The company I worked for decided to downsize and the older were the first to be fired, and then I had a painful divorce. I had hit rock bottom. When I did not believe anymore, the miracle happened. I met my wife online. I was not expecting 
much, but she is so nice, a beautiful person ... And here I am heading a small hotel that welcomes European tourists, especially Swiss, even former colleagues. For me it's a personal renaissance and a new economic adventure.

In a similar vein, Laura (introduced above) states:

When I rented this house I thought, 'Yeah, what do I do with all those rooms?' I don't have to live here on my own ... I'm not gonna sit behind the geraniums $\left[\right.$ Dutch proverb $\left.{ }^{8}\right]$. That's not my life. And what's more fun when you can share enthusiasm with guests and arrange a wonderful holiday for them?'

It is also important to add that some of them would have been living in poverty had they stayed in their country of origin. They experience what can be called 'a paradox of postcolonial precariousness' (Botterill, 2017): they have the feeling that they escaped from a precarious life in their home country and that thanks to international inequalities in purchasing power, with the same income they can be welloff in Morocco. A similar idea is developed by Hayes (2014), with his concept of geographic arbitrage that consists of relocating day-to-day expenses to low-cost locations in order to prevent precariousness of retirement security. Brigitte (Swiss, age 63), impressed by the sense of freedom she experienced during her first stay in Morocco, explains that with her old-age pension in Switzerland she would have lived in precarious conditions and under the control of the authorities had she remained there:

When I came for the first time on holiday, I saw the sun on the shantytowns. I said to myself ah, the sun also shines for the poor. I also saw a donkey and a Jaguar [car]. I told myself here there is room for everyone ... Following my divorce, the judge awarded me an alimony of 1,000 SF per month. I could not live on that in Switzerland; I took my old-age pension anticipated at 1,560 SF per month and came to live here.

In Morocco she has a roommate, a Moroccan woman, which allows her to share the costs. This is also the case for the Dutch couple Jan and Berta, aged 62 and 58, who felt forced to leave the Netherlands in search of a better, cheaper and more comfortable life. They were touring by car, first across Turkey, then across Morocco. When their car broke down close to N'kob, a rural community in the Atlas Mountains about 335 kilometres south-east of Marrakech, they decided to stay. Jan talked about the struggles they faced while still living in the Netherlands:

Well, we searched across the Netherlands, somewhere in a corner against the German border you had something to rent, for something around $€ 1,000$ a month ... No. Our income was not very high, we were already eating pancakes from the Aldi three times a week.

For two Swiss late-in-life migrants - Rita and Helga - and Dutch couple Klaas and Cora, health was the main or additional reason to migrate to Morocco. Rita (age 67) was divorced in Switzerland and suffered from very painful rheumatism. A friend 
recommended Marrakech and its dry and sunny climate. During a vacation, she noticed that her pains had decreased and her health had improved. She returned several times as a tourist and finally decided to buy a house with her savings and settle there. Thanks to her handicraft activities, she met a Moroccan craftsman with whom she shares her life. She is very active in asking the Swiss authorities for access to health insurance for the Swiss abroad: because she did not pay contributions during her working life in Morocco, she cannot benefit from Swiss health insurance like other Swiss expats. Klaas and Cora, both in their eighties, were tipped off by a friend to migrate to Morocco. As retirees they had been living in France for many years, in a house on a hill, which was no longer suitable when Klaas got mobility problems and Cora's rheumatic complaints worsened.

The migration decision for a few other interviewees in this age group is also connected to what is known as lifestyle migration, where relatively rich migrants settle in an often poorer country in search of a 'better life'. Apart from affective needs, no other primary needs play a role. It is a financially secure group that regards migration as a welcome adventure, not as a necessity. The couples Floris and Isabel and Louis and Olga - all Dutch, in their sixties - are prime examples of lifestyle migrants. They reside in affluent parts of Marrakech and are living a very comfortable, luxurious lifestyle. Floris and Isabel have lived all over the world and their children all enjoy a good life in different countries. The following quote makes it clear that Floris and Isabel are used to a wealthy lifestyle:

We have our own staff that we have selected and hired ourselves. We have a cook. And then Ilan, who you just saw here, here at the table, keeps the house clean. And then we have Said, he is the handyman and my driver too. One of the things I said, I want to move to Marrakech, but driving a car here ... No way.

This all seems very much related to Escher and Petermann's (2014) description of the medina of Marrakech as a neo-colonial paradise for lifestyle migrants.

Like those who migrated in early or middle adulthood, they are happy with their life in Morocco and none of them has concrete plans to return to Switzerland, the Netherlands or Belgium. Frédéric, a Swiss man, conveys the common sentiment of this migrant group: 'For the time being, the life I have here suits me very well, but who knows about the future.' Although they do not see themselves moving away anytime soon, they do not master the Arabic language at all, or just 'a few basic words' to get by.

Apart from in-laws (those married to a Moroccan) and personnel (those who have a business), contact with the local population is generally limited and distant. There are sporadic and brief contact moments when people leave the house, but friendships are rarely made. As Helga (from Switzerland) points out:

I know some merchants in the market. I always buy from the same. Friends, no. We don't have so many opportunities to meet Moroccans here who share the same daily life, the same hobbies.

Even those who make more regular small-talk with the locals have difficulties finding like-minded people. Charles (introduced above) explains: 
I have good relations with a lot of people here, but I cannot say that I have Moroccan friends. We don't have much opportunity to meet people our age with the same interests. So it's more like everyday interactions. I chat with the concierge of our building, with my mechanic, with the merchants at the market when I go shopping. It's nice, but we're not friends.

Both citations clearly indicate that these migrants try to integrate but have not been successful in establishing friendships. One sub-group - the lifestyle migrants - does seem to be less interested in doing so. To them, real friendships with Moroccans are not possible because of 'huge cultural differences'. The communication they have with staff is formal, work-related, and they experience less distress and tension than the middle-age group. Their communication and social contact seem to be more hierarchical. This manifests itself in the group's lower reliance on personnel that they hire for chores and activities within the house instead of for a business. Among them there are indications of strong feelings of superiority towards Moroccans. This is illustrated by the following statement of the Dutchman Louis (introduced above), who is enjoying retirement with his Dutch wife in one of the Marrakech golf resorts:

I'm going to give a very simple example. We have a Christian saying: 'When you give goodness, goodness comes back.' They [Moroccans] understand that differently. If you give goodness, it's seen as a weakness. And you take advantage of a weak person, see how far you can go. That's a whole different attitude.

In both cases, involuntary or voluntary, most of the migrants in this late-life group only have friends who are European expatriates, many of whom are (like them) married to a Moroccan. They regularly visit each other or meet somewhere 'to chat, share a beer' and discuss the situations and problems they all encounter. There are some exceptions though, especially among divorced women and those motivated by economic factors, who are more immersed in Moroccan society and have built true friendships with a few locals - like Laura (introduced above), who often participates in religious celebrations with the family of Fatima, a Moroccan woman she considers 'to be her youngest sister'. The same holds for Brigitte (also introduced above):

My co-tenant is a Berber woman. Her family adopted me. They invite me to all the parties, the sheep parties and everything.

Another example is the Dutch couple Jan and Berta in N'kob (also introduced above), two of the few foreigners living there. Jan became Muslim, often goes to the mosque, always wears a djellaba (a traditional garment worn in Morocco) and greets every man he encounters. The couple has very close contact with one Moroccan family whose male head also helped them buy and renovate their house.

\section{Conclusion}

We have seen the importance of the lifecourse, particularly the centrality of timing of migration, for understanding the motivations of INRRM to migrate and the 
subsequent social relationships they establish in Morocco. This perspective helps bring a more complex and dynamic look at lifestyle migration. Even when INRRM have the same origin in common and live in the same destination, because of different migration moments in their lives they do not necessarily share the same motivation to migrate nor do they build the same type of social relationships. Although contextual factors (e.g. North-South inequalities, climate differences) are important to understand INRRM experiences, there is a need to pay closer attention to lifecourse variables in order to understand some of the diversity of their lives in their new destinations. Thus, the distinction we made between three groups of migrants - early adulthood, middle-adulthood and late-in-life migrants to Morocco - is not purely analytical, it allows us to sketch a typology that grasps the specifics of each of the three groups in relation to their motivations to migrate and their social life in Morocco.

Migrants who moved to Morocco at the early stages of adulthood dealt with issues related to entering and exploring adult life. Compared to the other two groups, their motivations to migrate were clearly less related to previous tourist experiences in Morocco. They were quite concrete and very much in line with gendered roles. The main difference between men and women is fairly 'classical' in migration studies. While most of the women decided to join their future Moroccan fiancés in their country, the men migrated on their own initiative and mainly for professional reasons. They did not have many attachments in their home country and were prepared to live elsewhere. Still, both men and women aged in place, formed a couple and commonly a family, and had enough time to adapt to a new life and a new culture. They experienced a 'Moroccan' upper middle-class life, developing relationships with locals as well as with expatriates who shared similar characteristics. Their social network became thus more diversified when compared to INRRM who arrived later in Morocco.

What certainly differentiates middle-adulthood migrants to Morocco from early adult migrants is a now-or-never feeling related to a project of professional fulfilment (Therrien and Pellegrini, 2015). They knew that they had little time left to improve their standard of living before retirement, and saw Morocco as a country that offered the economic opportunities they were looking for, thanks to the tourist boom. Even though they were no longer young, they did not have family obligations that could keep them from embarking on a new adventure. The general idea was to escape from constraints in the country of origin plus have access to a higher standard of living and fulfil hedonistic perspectives in a setting with a better climate. This purpose is much in line with lifestyle migration (Benson and O'Reilly, 2009; Escher and Petermann, 2014). Most of these migrants live very much in their own expatriate world and around their work in tourism, only spending time with their business associates and sometimes gathering with other like-minded European migrants. In contrast to the first group, only a minority are married to a Moroccan or have a Moroccan partner. Contact with locals is characterised by ambivalence, combining everyday proximity and cultural distance. It is also marked by unintentionally hierarchical and complex relationships with personnel. In the framework of professional relationships they need to 'manage the encounter' (Therrien and Pellegrini, 2015) with their employees, while such everyday encounters are crossed by mistrust and cultural misunderstandings. 
The group of late-in-life migrants is more diverse than the two previously discussed groups. Although most in this group are retired, the motives behind their migration differ considerably. Still, most of them experienced disruptive life events before migrating and expected to find in Morocco a second chance to build a better life. Like those who migrated in early adulthood, this group is also marked by clear gender differences but the gender roles are reversed: men followed their future Moroccan wives, while women were more attracted by the general atmosphere and the individual freedom they hoped to find in Morocco. While men were looking for a new stable relationship, women were not afraid to be alone, even though some also found a partner in Morocco later on.

In this fairly heterogeneous group, the more affluent found more purchasing power to realise their lifestyle aspirations, while those with more precarious finances could significantly improve their quality of life compared to their home country. Many migrants wanted to experience cultural otherness and could experience it, yet most interact mainly with European expatriates and experience difficulties developing close contacts with the local population. Unlike the second group, they are not obliged to have intensive instrumental professional relationships with the local population and manage polite but relative distant relations with them.

This exploratory typology shows how important it is to consider a lifecourse perspective, especially the timing of migration, to understand European INRRM to Morocco. Depending on the moment in their lifecourse and their past trajectories, interviewees had different motivations to move to the reception country based on opportunities and constraints they experienced in their country of residence and the new opportunities they expected to find in Morocco. Timing of migration has not been really considered by lifestyle migration research. Motives for migration are assumed to be largely the same whatever the moment of migration in the lifecourse: quest for meaningful experiences and desire for elsewhereness in places with a nice climate and a better quality of life (Williams et al., 2000; Benson and O'Reilly, 2009; Therrien and Pellegrini, 2015). Indeed, these drives are important, but not equally generalisable to all INRRM. Findings also show that another lifecourse dimension the linked lives dimension - appears to be important both as a positive reason for migration to Morocco and as a non-retaining reason to leave one's country of origin. Indeed, many interviewees moved to Morocco because they wanted to develop a romantic relationship with a native Moroccan. Most of the women migrated in early adulthood to marry a Moroccan man. This was also the case for most of the men in late adulthood who married a Moroccan woman. On the other hand, in all the three lifestage groups, leaving the home country was facilitated by a lack of strong attachments: in early adulthood because all the interviewees were single, in middle adulthood because they lacked important family obligations, and in late adulthood because most were divorced or their children were adults.

The timing of migration is also relevant to understand the types of social relationships that INRRM establish at the local level. This is also a contribution of our article, from a lifecourse perspective, to the literature on lifestyle migration. Indeed, the possibility of developing lasting relationships with the local population is greater for those who arrived early in adulthood. Time and shared experiences during adult life work in their favour and allow them to establish friendships, especially with upper middle-class Moroccans. For those who migrated later in their 
adulthood it is difficult to develop close relationships with locals. This brings us to some theoretical aspects already identified by the literature on lifestyle migration but particularly relevant when combined with a lifecourse perspective. The context of globalisation fuels the imagination of Europeans and enables access to new tourist destinations, to new transnational life experiences that reinforce cosmopolitan identities and dispositions to live elsewhere (Gustafson, 2008; Benson and O'Reilly, 2009). The asymmetry of economic and political power as well as the inequalities in standard of living between the global North and the global South additionally facilitate the migration of Europeans to Morocco, who can thus concretise their projects elsewhere. At the same time, this asymmetry and inequality do not allow the establishment of 'trusting' social relationships between expatriates and locals, especially in the case of middle-age professional migrants and, to a lesser extent, late-in-life migrants.

Our interviewees told us that they were attracted to Morocco as a more 'authentic' country, but also by the kindness of its people; and yet at the same time they complain about the difficulty of developing closer relationships with Moroccans. This is part of the paradox of postcolonialism (Benson, 2013), which will probably continue to haunt these middle-adulthood and late-in-life migrants. Indeed, they have changed their social status because, compared to the situation in their country of origin, they have a higher income than the vast majority of the local population and some employ service staff. At the same time, in a postcolonial setting they are probably identified by the local population as part of a dominant group and treated with respect by the authorities, yet also defined as foreigners. In this sense they have gone from a certain invisibility in their home country to a visibility that constitutes both a privilege and a form of marginality.

This article has focused on the situation of European INRRM in Morocco. It would be interesting to explore whether the trends observed for the three migrant groups in that country are similar to those found in other global South countries. In addition, as the interviewees are still relatively young and mostly healthy, one may wonder what will happen as they age and health problems start affecting their daily autonomy. Which forms of care will they have access to? Under which conditions will they have access to the Moroccan health-care system? The answer to these questions will probably influence their decisions to either stay in Morocco or return to their home countries. These new issues deserve further exploration from a lifecourse perspective.

Acknowledgements. We are grateful to HES-SO which has financed the Swiss part of our research. We are also grateful to the anonymous reviewers for their useful comments on previous versions of this article.

Financial support. This work was supported by HES-SO.

\section{Notes}

1 Morocco held two regularisation programmes. The initial programme took place in 2014 . A further regularisation process took place in 2017. According to the World Bank, more than 25,000 individuals from 116 countries received one-year residency permits in the 2014 regularisation process. This population came mostly from sub-Saharan Africa and Syria. The second campaign of 2017 legalised around 28,000 individuals (Jacobs, 2019). However, it is estimated that 700,000 sub-Saharan African migrants reside in Morocco, most of them with an irregular legal status (El Ghazouani, 2019). 
2 See https://www.econostrum.info/Libra-Capital-va-proposer-aux-seniors-europeens-des-maisons-deretraite-au-Maroc_a4315.html.

3 See https://www.moroccoworldnews.com/2019/06/275559/tourist-visits-morocco-increase/.

4 Figures from https://oxfordbusinessgroup.com/overview/turning-tide-sector-expected-continue-its-recovery-back-strong-performance-2017.

5 Foreigners have two types of administrative status. Either they are residents and have a residence permit, which allows them access to local facilities such as opening a bank account in the local currency, or they are 'tourists', in other words they live in Morocco with a tourist visa, which gives them the right to stay in the country for three months; the visa is extendable once in theory but much more in practice, and requires them to leave the territory to renew it. Many European residents opt for this second possibility and are invisible to official statistics (Terrazoni, 2015).

6 Francophone Belgians were not included because interviewers from the Dutch team do not speak fluent French.

7 INRRM from the three lifestage groups had different motivations for migration and experienced different outcomes depending on the timing of migration, yet this does not mean they do not socialise and mix with each other in Morocco according to shared dimensions such as same national origin, same language or similar lifestyles. Still, contacts tend to be more intense with people who migrated in the same lifecourse period. 8 These flowers are typically put in boxes below the window at the façade of Dutch houses. So if you are behind the geraniums you are inside the house, not being active.

\section{References}

Bailey A and Mulder CH (2017) Highly skilled migration between the Global North and South: gender, life courses and institutions. Journal of Ethnic and Migration Studies 43, 2689-2703.

Bantman-Masum E (2015) Lifestyle transmigration: understanding a hypermobile minority in Mérida, Mexico. Journal of Latin American Geography 14, 101-117.

Benson MC (2011) The British in Rural France: Lifestyle Migration and the Ongoing Quest for a Better Way of Life. Manchester, UK: Manchester University Press.

Benson MC (2013) Postcoloniality and privilege in new lifestyle flows: the case of North Americans in Panama. Mobilities 8, 313-330.

Benson M and O'Reilly K (2009) Migration and the search for a better way of life: a critical exploration of lifestyle migration. The Sociological Review 57, 608-625.

Bernard A, Bell M and Charles-Edwards E (2014) Life-course transitions and the age profile of internal migration. Population and Development Review 40, 213-239.

Berriane M, de Haas H and Natter K (2015) Introduction: revisiting Moroccan migrations. Journal of North African Studies 20, 503-521.

Bertaux D and Kohli M (1984) The life story approach: a continental view. Annual Review of Sociology 10, 215-237.

Bettin G, Cela E and Fokkema T (2018) Return intentions over the life course: evidence on the effects of life events from a longitudinal sample of first- and second-generation Turkish migrants in Germany. Demographic Research 39, 1009-1038.

Bolzman C, Bernardi L and Le Goff J-M (2017) Introduction: situating children of migrants across borders and origins. In Bolzman C, Bernardi L and Le Goff J-M (eds), Situating Children of Migrants Across Borders and Origins. A Methodological Overview. Amsterdam: Springer Open, pp. 1-21.

Botterill K (2017) Discordant lifestyle mobilities in East Asia: privilege and precarity of British retirement in Thailand. Population, Space and Place 23, e2011.

Bousta R (2007) From tourism to new forms of migration: Europeans in Marrakesh. In Geoffroy C and Sibley R (eds), Going Abroad: Travel, Tourism and Migration. Cross-cultural Perspectives on Mobility. Newcastle upon Tyne, UK: Cambridge Scholars, pp. 158-166.

Buller H and Hoggart K (1994) The social integration of British home owners into French rural communities. Journal of Rural Studies 10, 197-210.

Casado-Díaz MA, Kaiser C and Warnes AM (2004) Northern European retired residents in nine southern European areas: characteristics, motivations and adjustment. Ageing \& Society 24, 353-381. 
Clark WAV and Huang Y (2003) The life course and residential mobility in British housing markets. Environment and Planning A: Economy and Space 35, 323-339.

Croitoru A (2018) Gendered migratory pathways: exploring the work trajectories of long-term Romanian migrants. In Vlase I and Voice B (eds), Gender, Family, and Adaptation of Migrants in Europe: A Life Course Perspective. Cham, Switzerland: Palgrave Macmillan, pp. 93-115.

Dumont GL (2006) Les territoires face au vieillissement en France et en Europe. Géographie, politique, prospective. Paris: Ellipses.

Edmonston B (2013) Life course perspectives on migration. Canadian Studies in Population 40, 1-8.

Elder Jr GH (1994) Time, human agency, and social change: perspectives on the life course. Social Psychology Quarterly 57, 4-15.

Elder Jr GH and Giele JZ (2009) Life course studies. An evolving field. In Elder Jr GH and Giele JZ (eds), The Craft of Life Course Research. New York, NY: Guilford Press, pp. 1-28.

El Ghazouani D (2019) A growing destination for Sub-Saharan Africans, Morocco wrestles with immigrant integration. Migration Information Source. Available at https://www.migrationpolicy.org/article/growingdestination-sub-saharan-africans-morocco.

Escher A and Petermann S (2014) Marrakech Medina. Neocolonial paradise for lifestyle migrants? In Janoschka M and Haas H (eds), Contested Spatialities, Lifestyle Migration and Residential Tourism. London: Routledge, pp. 29-46.

Findlay A, McCollum D, Coulter R and Gayle V (2015) New mobilities across the lifecourse: a framework for analysing demographically linked drivers of migration. Population, Space and Place 21, 390-402.

Gallo E (2006) Italy is not a good place for men: narratives of place, marriage and masculinity among Malayali migrants in Rome. Global Networks 6, 357-372.

Geist C and McManus P (2008) Geographical mobility over the life course: motivations and implications. Population, Space and Place 14, 283-303.

Gilmartin M and Migge B (2016) Migrant mothers and the geographies of belonging. Gender, Place of Culture 23, 147-161.

Gomensoro A and Bolzman C (2019) When children of immigrants come of age: a longitudinal perspective on labour market outcomes in Switzerland. TREE, Bern, Working Paper Series 2.

Guissé I and Bolzman C (2014) Migration de retraités européens au Maroc. Tendances, pratiques et impact. Etude de cas des Suisses retraités au Maroc. In Proceedings of Moroccan Migrations: Transformations, Transitions and Future Prospects, Fez, Morocco, May. Oxford: International Migration Institute, University of Oxford.

Gustafson P (2008) Transnationalism in retirement migration: the case of North European retirees in Spain. Ethnic and Racial Studies 31, 451-475.

Hayes M (2014) 'We gained a lot over what we would have had': the geographic arbitrage of North American lifestyle migrants to Cuenca, Ecuador. Journal of Ethnic and Migration Studies 40, 1953-1971.

Huber A and O'Reilly K (2004) The construction of Heimat under conditions of individualised modernity: Swiss and British elderly migrants in Spain. Ageing \& Society 24, 327-352.

Jacobs A (2019) Morocco's Migration Policy: Understanding the Contradiction Between Policy and Reality. Moroccan Institute for Policy Analysis. Available at https://mipa.institute/6872.

Josselson R and Lieblich A (eds) (1993) The Narrative Study of Lives, Vol. 1. Newbury Park, CA: Sage.

Khachani M (2011) La question migratoire au Maroc: données récentes (CARIM Notes d'analyse et de synthèse 71). Available at https://cadmus.eui.eu/handle/1814/19877.

King R, Cela E, Morettini G and Fokkema T (2019) The Marche: Italy's new frontier for international migration. Population, Space and Place 25, e2241.

Kirk K, Bal H and Janssen SR (2017) Migrants in liminal time and space: an exploration of the experiences of highly skilled Indian bachelors in Amsterdam. Journal of Ethnic and Migration Studies 43, 2771-2787.

Kley S (2011) Explaining the stages of migration within a life-course framework. European Sociological Review 27, 469-486.

Kõu A, Mulder CH and Bailey A (2017) 'For the sake of the family and future': the linked lives of highly skilled Indian migrants. Journal of Ethnic and Migration Studies 43, 2788-2805.

Kulu H and Milewski N (2007) Family change and migration in the life course: an introduction. Demographic Research 17, 567-590.

Lardiès Bosque R, Guillén JC and Montes-De-Oca V (2016) Retirement migration and transnationalism in northern Mexico. Journal of Ethnic and Migration Studies 42, 816-833. 
Li S-M (2004) Life course and residential mobility in Beijing, China. Environment and Planning A: Economy and Space 36, 24-43.

Lulle A and King R (2016) Ageing, Gender, and Labour Migration. New York, NY: Palgrave Macmillan.

Luong G, Charles S and Fingerman K (2011) Better with age: social relationships across adulthood. Journal of Social and Personal Relationships 28, 9-23.

Martiniello $\mathbf{M}$ and Bousseta $\mathbf{H}$ (2008) Les pratiques transnationales des immigrés chinois et marocains de Belgique. Revue européenne des migrations internationales 24, 45-66.

Mulder CH (1993) Migration Dynamics: A Life Course Approach (PhD thesis). University of Amsterdam, Amsterdam.

Mulder CH and Wagner M (1993) Migration and marriage in the life course: a method for studying synchronized events. European Journal of Population 9, 55-76.

Office fédéral de la statistique (2017) Suisses de l'étranger selon le pays de résidence, le droit de cité, le sexe et la classe d'âge. Available at https://www.bfs.admin.ch/bfs/fr/home/actualites/quoi-de-neuf.assetdetail. 4883766.html.

Ono M (2015) Commoditization of lifestyle migration: Japanese retirees in Malaysia. Mobilities 10, 609627.

Organisation for Economic Co-operation and Development (2017) Le paysage des migrations au Maroc. In Interactions entre politiques publiques, migrations et développement au Maroc. Paris: Editions OCDE, pp. 39-60.

Repetti M and Bolzman C (2020) Ageing abroad. The case of Swiss nationals in Morocco and Spain. Swiss Review of Sociology 46, 199-217.

Rosenthal G (1993) Reconstruction of life stories: principles of selection in generating stories for narrative biographical interviews. In Josselson $\mathrm{R}$ and Lieblich $\mathrm{A}$ (eds), The Narrative Study of Lives, Vol. 1. Newbury Park, CA: Sage, pp. 59-91.

Sall M (2009) Caractéristiques et enjeux de la nouvelle économie résidentielle dans la station balnéaire de Saly Portudal et sur la Petite Côte au Sénégal. ESSACHESS - Journal for Communication Studies 2, 57-71.

Sampaio D (2017) Ageing 'on the Edge': Later-life Migration in the Azores (PhD thesis). University of Sussex, Brighton, UK.

Shaw A and Charsley K (2006) Rishtas: adding emotion to strategy in understanding British Pakistani transnational marriages. Global Networks 6, 405-421.

Smits J, Mulder CH and Hooimeijer P (2003) Changing gender roles, shifting power balance and longdistance migration of couples. Urban Studies 40, 603-613.

Solano G (2019) The mixed embeddedness of transnational migrant entrepreneurs: Moroccans in Amsterdam and Milan. Journal of Ethnic and Migration Studies 46, 2067-2085.

Terrazzoni L (2015) Les nouveaux migrants français à Essaouira et Marrakech. In Khrouz N and Lanza N (eds), Migrants au Maroc. Cosmopolitisme, présence d'étrangers et transformations sociales. Rabat: Centre Jacques-Berque and Fondation Konrad Adenauer Stiftung, pp. 24-30.

Therrien K and Pellegrini C (2015) French migrants in Morocco: from a desire for elsewhereness to an ambivalent reality. Journal of North African Studies 20, 605-621.

Vlase I and Voicu B (2018) Gender, Family, and Adaptation of Migrants in Europe. A Life Course Perspective. Cham, Switzerland: Palgrave Macmillan.

Wall K and Bolzman C (2014) Mapping the new plurality of transnational families: a life course perspective. In Baldassar L and Merla L (eds), Transnational Families, Migration and the Circulation of Care: Understanding Mobility and Absence in Family Life. Abingdon, UK: Routledge, pp. 68-96.

Widmer E (2010) Family Configurations. A Structural Approach to Family Diversity. Farnham, UK: Ashgate.

Williams AM, King R, Warnes A and Patterson G (2000) Tourism and international retirement migration: new forms of an old relationship in southern Europe. Tourism Geographies 2, 28-49.

Wingens M, Windzio M, de Valk $\mathbf{H}$ and Aybek C (2011) A Life-course Perspective on Migration and Integration. Dordrecht, The Netherlands: Springer.

Cite this article: Bolzman C, Fokkema T, Guissé I, van Dalen D (2021). Starting a new life in the South? Swiss, Dutch and Flemish ageing in Morocco: a lifecourse perspective. Ageing \& Society 1-27. https:// doi.org/10.1017/S0144686X20001804 